\title{
POSSSIBILITIES OF THE PUPIL'S SELF-CONCEPT DEVELOPMENT IN THE FIELD OF TECHNICAL EDUCATION AT THE PRIMARY SCHOOL
}

\author{
Pavlína ČÁSTKOVA*, Univerzita Palackého v Olomouci \\ Jiř́ KROPÁČ , Univerzita Palackého v Olomouci
}

Přijato: 16. 2. 2015 / Akceptováno: 25. 5. 2015

Typ článku: Teoretická studie

DOI: $10.5507 /$ jtie.2015.009

Abstract: The article deals with the development of pupil's personal qualities in the field of technical education at the level of primary school (ISCED1). Due to its interdisciplinary nature, the primary school provides good opportunities to develop not only the knowledge base, but also pupil's personal qualities through a creative, collaborative or a problem activity. Pupil's self-concept is presented as a construct based on the information provided by the student's environment. In this sense, the self-assessment in the field of technical education is presented as an integral component of the self-assessment, which affects its formation. The article includes an investigative study mapping the teachers' perceptions of the factors determining the creation of the pupil's self-image.

Key words: technical education, primary school, self-concept, self-assessment.

\section{MOŽNOSTI ROZVOJE SEBEPOJETÍ ŽÁKA V TECHNICKÉ VÝCHOVĚ NA PRIMÁRNÍ ŠKOLE}

Resumé: Článek se zabývá problematikou rozvoje osobnostních kvalit žáka $v$ oblasti technické výchovy na primární škole. Vzhledem $k$ interdisciplinárnímu charakteru poskytuje primární škola dobré možnosti k rozvoji nejen poznatkové báze, ale také osobnostnich kvalit žáka, a to prostřednictvím tvưrčí, kooperativní či problémové činnosti. Pro vytváření sebepojetí je významná jak aktivita samotná, tak činnost kooperativní, která umožňuje reflexi vlastní činnosti $i$ názorů ostatních. V tomto smyslu je sebehodnocení v technické výchově prezentováno jako nedilná složka sebepojetí, která ovlivňuje jeho formování. Součástí článku je výzkumná sonda mapujíci učitelské vnímáni faktorů rozhodujicich při vytvárení žákova sebepojetí.

Klíčová slova: technická výchova, primární škola, sebepojetí, sebehodnocení.

5. - This journal was approved on 2015-04-23 according to ERIH PLUS criteria for inclusion.

*Autor pro korespondenci: pavlina.castkova@upol.cz 


\section{1 Úvod}

Výuka technických předmětů na základních školách v České republice vybavuje žáky obecně technickými způsobilostmi potřebnými pro zvládání problematických situací spojených s užitím techniky, které jsou aktuální nebo které je možno v budoucnu předpokládat. Ovšem kromě vytváření porozumění technickým systémům a činnostem a rozvíjení pro činnost $s$ technikou důležitých předpokladů (kritické myšlení, technické myšlení, psychomotorické dovednosti) se tato výuka podílí na rozvoji osobnosti žáků. Znamená to, že $\mathrm{v}$ technických předmětech jsou spoluvytvářeny také postoje žáků ke světu a rovněž sebepojetí žáků. Úkolem technických předmětů je tedy jednak zabránit technickému analfabetismu (opak technické gramotnosti), ale také vytvářet či spoluvytvářet představu jedince o svém já a to ve vztahu $\mathrm{k}$ technice a především $\mathrm{k}$ činnostem $\mathrm{s}$ technikou. Mezi cíle technické výchovy na primární škole patří, kromě rozvíjení poznatků o technice a jejím postavení v životě lidstva, také rozvoj dovedností řešení problémů (Röben, 2013). S tím jsou spojeny kategorie, jako jsou tvořivé technické myšlení, projektové a kooperativní vyučování nebo rozvoj schopnosti hodnocení techniky i sebehodnocení. Zde hodnocení techniky chápeme také jako obecnou schopnost hodnotit techniku, která vede žáky k následnému hodnocení vlastní činnosti s technikou (Kropáč st., Kropáč ml. 2009).

Pro uvedené úkoly mají technické předměty realizované ve všeobecném vzdělávání na nižších stupních škol ze své podstaty dobré možnosti. Ty jsou předurčeny realizací problémově i tvořivě zaměřené aktivní kooperativní činnosti žáka v tématech potřebných a praxi blízkých, současně umožňujících aplikaci dřive žáky osvojeného poznání, tvorbu žákovy hodnotové orientace a kladného vztahu $\mathrm{k}$ technické výchově. Veškeré aktivity jsou průběžné doprovázeny hodnocením žákovy činnosti, které provádí učitel. Na základě těchto poznatků je záměrem článku je prezentovat souvislosti vytváření sebepojetí žáka při výuce technických předmětů na prvním stupni základních škol. Učitelovo hodnocení je ovlivněno velkým množství skutečností, které jsou součástí vzájemného vztahu učitel-žák. Mezi nejzásadnější determinanty patří chápání samotného žáka učitelem a od toho se odvíjející celkové pojetí vyučování (výukové strategie). Funguje-li učitel jako jediný hodnotitel, je na proces učení nahlíženo pouze jedním (přestože odborným) pohledem. $\mathrm{V}$ př́padě, že $\mathrm{v}$ duchu současné pedagogiky vnímáme žáka jako spolutvůrce výchovného procesu, pak je jeho participace nezbytná i při hodnocení výsledků učební činnosti.

\section{Pojem sebepojetí a jeho souvislosti s výukou technických předmětů na základní škole}

Pojem sebepojetí bývá charakterizován jako relativně stabilní představa jedince o sobě či svém já, to jak jedinec vidí sám sebe. Sebepojetí je vícesložkový, integrovaný konstrukt, mj. zahrnuje a je „výsledkem“ sebepoznání založeného především na podnětech sociálních, osobnostních a situačních, na úspěších či neúspěších v činnosti, je tedy značně závislé na informacích poskytovaných okolím (spolužáky či učitelem). Sebepojetí lze chápat i jako výčet toho, co jedinec dovede, ke komu patř́ atp., především ale zahrnuje obecné generalizace, s nimiž souvisí vlastnosti, zvnitřnělé společenské normy, schopnosti, vědomosti, hodnoty, postoje a sociální role, všechno, na základě čeho se subjekt charakterizuje a hodnotí. Jde ovšem zejména o charakteristiky sebeprofilující. Sebepojetí zahrnuje otázky: - Kdo a jaký jsem? - Jaký bych chtěl či měl být? Kam směřuji? - Co mohu dokázat? Z hlediska žáka nejde tedy jen o otázku reálného Já - 
kdo jsem a jaký jsem, ale také o otázku ideálního Já -kým a jaký chci být (Čáp, Mareš, 2001).

Sebepojetí zahrnuje různé dílčí aspekty Vágnerová (2010) člení sebepojetí do tř́ základních oblastí:

- kognitivní složka: obsah sebepojetí a jeho struktury

- afektivní složka: emociální vztah k sobě (názory na sebe sama, vztah k sobě, sebeakceptace, sebehodnocení,

- konativní složka: motivace, seberegulace.

Sebepojetí jako obraz o sobě je výsledkem sebepoznání, což je kognitivní složka sebepojetí závislá na schopnosti reflexe, sebeobraz je pak dle Fontany (2003, s. 246) „naučený a závisí na popisech poskytovaných okolim “. V tomto smyslu potom probíhá jako poznávání svých potřeb, motivů, zájmů, emocí a myšlení. $Z$ hlediska stati jde zejména o žákovo uvědomování si svých psychických vlastností, možností i omezení ve vztahu $\mathrm{k}$ technice, uvědomění si možností ovládání a uživání svých daností (rozumových, emočních, fyzických, způsobu myšlení - konvergentní nebo divergentní, aj.) v souvislostech s technikou. Žák si i v technických souvislostech uvědomuje co jsem, co mohu zvládnout, co se chce, co chci já, k čemu se hodím, co mohu na sobě změnit, chci to změnit, jak se ovládám, trpím stresem, zvládám zátěž atp. Takto vznikající obraz - sebepojetí, jak upozorňuje Fontana (2003), může i nemusí být správný; odvisí od vnějších, přejímaných informací.

Žák tedy své sebepojetí na základě kontinuálně probíhajícího sebepoznávání může upřesňovat, činit více adekvátním a tím i více stabilním (Fontana, 2003). To je možno výukou technických předmětů na primární škole cíleně podporovat. Přiměřené a stabilní sebepojetí je výrazem zralosti žáka i v zaměření na techniku, i zde je předpokladem dobrého rozhodování, včetně rozhodování ve složitějších situacích. Je však třeba, aby sebepoznání bylo podloženo prožitkem situací spojených s technikou.

Technické předměty tedy mohou nabízet interakci se sociálním prostředím souvisejícím s oblastí techniky, nezbytným $\mathrm{k}$ vytvárení „sebepojetí žáka vztaženého k technice“. Ve výše uvedeném byly sebepojetí, postup jeho vytváření i vyústění v aspekty konativní popsány jako „obsahově“ relativně jednotné, ucelené, uvedli jsme však, že jde o vícesložkový konstrukt. Je tedy otázka, zda vymezení sebepojetí k určité oblasti, zde $\mathrm{k}$ technice, navíc $\mathrm{k}$ žáku primárního vzdělávání, je možné. I. Mammes (2013), v návaznosti na další autory, prezentuje sebepojetí (Selbstkonzept) jako multidimenzionální, hierarchicky členěný konstrukt, v němž se „výsledky sebepoznáni'“ ve specifických oblastech (Handlungs- und Verfahrensweisen) odrážejí v dílčích sebepojetích či dílčích složkách sebepojetí (Teilselbstkonzept).

Škola může žáky dobře vybavit představami o jejich „předpokladech“ pro zvládání požadavků „,celé“ výuky i pro jednotlivé vyučovací předměty (zde vytváří potřebný referenční rámec). Pro praktické situace $\mathrm{v}$ očekávaném profesním i neprofesním životě žáka má prostor menší. Může se to týkat i řešení situací spojených $\mathrm{s}$ vytvářením a užíváním některých oblastí techniky nebo situací spojených s hodnocením (sebehodnocením) a rozhodováním se pro technické profese. Menší prostor věnovaný výuce technických předmětů je tedy třeba využít pro vytvoření sebepojetí zacíleného $\mathrm{k}$ této významné oblasti životní reality. 
3 Význam žákovy cílevědomé aktivity, zážitky, zkušenosti pro vytváření sebepojetí

Aktivní činnost žákủ je všeobecným rysem technických předmětů, jejichž prvořadým záměrem je vybavit žáky kompetencemi pro „život s technikou“. Tato aktivní činnost je výrazně zaměřena na vytváření vztahů a postojů především $\mathrm{k}$ technice, proto má přinášet žákovi pozitivní podněty, zážitky ( $\mathrm{z}$ úspěšného řešení, ze zdařilého výrobku, ze splnění užitečného úkolu atp.). Zážitek chápeme v souladu s (Hartl, Hartlová, 2004, s. 701) za duševní jev, který ,jedinec proživá (vnímání, myšlení, představivost), vždy vnitřní, subjektivní, citově provázaný; zdroj osobni zkušenosti... “ Zážitek tedy vzniká na základě zúčastněného prožití situace - situace související s technikou. Prezentace významu zážitku (prožívání) pro vnímání sebe jako osobnosti s danými vlastnostmi, kterou předložil Jirásek (2014), je podle našeho názoru platná i pro téma tohoto článku.

Pro vytváření sebepojetí je významná jak aktivita samostatná, při níž žák bezprostředně prožívá vlastní úspěchy či neúspěchy, tak činnost kooperativní, která umožňuje zaujetí místa mezi kooperujícími, zhodnocení vlastní výkonosti, reflexe názorů ostatních o sobě; zde netřeba dokazovat možnosti technických předmětů. Soudobá teorie kooperativní výuky se opírá mj. o teorii skupinového vyučování, což přeneseně platí i pro praxi výuky, podrobněji viz Kasíková (2001). Dělením žáků do skupin jsou pro kooperaci jen vytvořeny podmínky. Kooperativní výuka spočívá až ve spolupráci ve skupině, v sociální interakci, jejímž významným prostředkem je dialog (Kolár̆, Šikulová, 2007). Přri kooperaci je úspěch jednotlivce - dosažení zadaného cíle výuky vázán na úspěch skupiny, spolupracujících členů skupiny. Učivo o technice si žák osvojuje ve skupinové interakci, ve vztazích k ostatním a vlastní prací „pro skupinu“. Součástí učení je potom také formování sociálních dovedností pro týmovou práci jako př́ispěvek osobnostně sociálnímu a intelektuálnímu rozvoji žáka. Což potvrzují také výsledky výzkumu kooperativního vyučování na základní škole. (Čábalová, 2006) Žákovo nacházení místa ve skupině je spojeno se sebehodnocením, to umožňuje vytváření sebepojetí ve vztahu $\mathrm{k}$ technice.

Jedním $\mathrm{z}$ prŕspěvků rozvoji žáka $\mathrm{v}$ rámci výuky technických předmětů je vznik zkušeností z prostředí blízkého realitě. Pojem zkušenost považují autoři pedagogického slovníku (Průcha, Walterová, Mareš, 2003, s. 312) za mnohoznačný. Může jít o poznávání světa opírající se o smysly, prožitky, sociální styk a praktickou činnost či o souhrn individuálních znalostí a dovedností, návyků, zájmů, prožitků, sociálních vztahů. Vztažena může být $\mathrm{k}$ jedinci, potom se obtížně se předává jiným (existuje i kolektivní zkušenost). Ve škole jako jinde platí, že při poznávání (okolí i sebe) má značný význam zkušenost, tedy dřive poznané a prožité. Poznávané je interpretováno na základě způsobu porozumění dříve vnímaných skutečností; tato teze patří $\mathrm{k}$ základním pro konstruktivistické pojetí výuky. „To, co má subjekt ve své mysli již vybudováno, mu poskytuje komplexni schéma, rámec poznání, které slouži jako základ pro nové poznání, které teprve bude vystavěno“ (Grecmanová, Urbanovská, Novotný, 2000, s. 20). Další myšlenka konstruktivismu je, že žák se učí to, co jej zajímá, co považuje za užitečné a co „mu funguje“ (viabilita), funkčnost poznání je tedy určitým měřítkem správnosti poznání (Riedl, 2003, s. 30-31). Možnost ověření poznaného, i toho, co žák zjistil „o sobě“ při aktivitách adekvátních procesu výuky technických předmětů na základní škole může tedy být významným faktorem rozvoje sebepojetí. 


\section{Sebehodnocení v technické výchově jako jedna ze složek sebepojetí}

Jestliže vnímáme sebepojetí jako produkt sociálního učení v procesu interakce učitelžák, pak můžeme sebehodnocení chápat jako výsledek srovnávání a sebeposuzování na základě vlastní činnosti podle určitých kritérií. Základy těchto kritérií jsou položeny již v dětském období na podkladě hodnocení významných osob v okolí žáka. (Blatný, 2010) Období mladšího školního věku je dobou adaptace na nové podmínky, řešení nových situací a setkávání se s novými lidmi. Úspěch i neúspěch je vnímán v kontextu vztahů k dospělým osobám, které představují určitý zdroj jistoty a lásky. Žák je ve všech svých činnostech stavěn do situací, ve kterých se musí rozhodnout pro konkrétní postup řešení. Nedílnou součástí každého rozhodování je proces hodnocení. To poskytuje žákovi zpětnou vazbu, a tím formuje jeho představu o správnosti použitých postupů, které si pro řešení úloh zvolil. Právě volba vlastního způsobu řešení úlohy podporuje rozvoj žákovy tvořivosti a vymezuje jeho chápání pedagogických situací a souvislostí.

Učitel, jeho názory a hodnocení jsou v nižších ročnících primární školy obzvláště významné. Žák učitelovy výroky často bere za své a na jejich základě si utváŕí obraz o sobě samém. Vhodným poskytováním zpětné vazby ze strany učitele je možné vést žáky k samostatně řízeným sebehodnotícím aktivitám. Tato činnost však nemůže být u žáků primární školy očekávána ze dne na den, ale je předmětem dlouhodobého procesu, v němž hraje hlavní roli učitel. S kurikulární reformou a s ní spojenou snahou o změnu v prŕístupu k vyučování i učení žáka vrůstá potřeba učitelů uplatňovat moderní způsoby hodnocení výsledků vzdělávání. Hodnocení má nejen poskytovat zpětnou vazbu o vlastních výkonech, ale má žákovi především pomáhat. $\mathrm{K}$ tomu, aby tento účel plnilo je však třeba dodržovat určité principy. V kontextu technické výchovy je třeba, aby učitel bral v potaz rozdílné vstupní podmínky (znalosti, zkušenosti), jedinečnost poznávacího procesu žáka a především žákův sebeobraz. (Koštálová, Miková, Stang, 2012)

Učitelovo hodnocení je ovlivněno velkým množství skutečností, které jsou součástí vzájemné interakce učitel-žák. Mezi nejzásadnější determinanty patří chápání samotného žáka učitelem a od toho se odvíjející učitelovo pojetí vyučování (výukové strategie). Má-li učitel v úmyslu podat žákovi zpětnou vazbu na základě vlastního pozorování a analýzy žákovy práce, je třeba respektovat osobností a sociální kontext výuky. $\mathrm{V}$ edukační realitě jsou tyto faktory zohledněny prostřednictvím modifikace výchovněvzdělávacích cílů. Učitel by neměl žákův výkon poměřovat se standardizovaným popisem cílů, ale spíše posuzovat zadání cílů v souvislosti s žákovými osobnostními dispozicemi. Zamyšlením nad činiteli ovlivňujícími žákův výkon ve výuce se učiteli naskytuje možnost, jak tyto faktory využít ve prospěch jeho učení se (Č́stková Stolinská, 2014).

Učitelé často automaticky očekávají, že žák bude schopen regulovat vlastní učení na základě jejich hodnocení. K tomu je však třeba vybavit žáky schopností reálně hodnotit vlastní práci - sebehodnotit (se). Prvním krokem tohoto procesu je změna vnímání hodnocení jako učitelova nástroje a vytvoření z ,diagnostického prostředku nástroj pracovni“". (Slavík, 1999) Funguje-li učitel jako jediný hodnotitel, je na proces učení nahlíženo pouze jedním (přestože odborným) pohledem. V případě, že v duchu současné pedagogiky vnímáme žáka jako spolutvůrce výchovného procesu, pak je jeho participace nezbytná i při hodnocení výsledků učební činnosti. Kladná či záporná zpětná vazba ze strany učitele ovlivní jeho výkon na poměrně krátkou dobu, přesto se učitelovo hodnocení stává významným faktorem spoluutvářejícím žákovo sebepojetí. 
Hodnocení vlastní práce umožní žákovi regulovat svou činnost, čímž ovlivní vlastní učení a učí se přijímat zodpovědnost za jeho výsledky. Sebehodnocení žáků v technické výchově je jednou z činností, při které žák konfrontuje své vlastní názory na sebe sama s názory učitele i ostatních žáků. $Z$ psychologického hlediska se pak jedná o emoční reprezentaci vnímání vlastní hodnoty a kompetence. (Blatný, 2010)

Sebehodnotící dovednosti je třeba systematicky rozvíjet napríklad prostřednictvím návodných reflektivních otázek. Mezi tyto otázky patří dotazy typu: Co nového jsem se dozvědèl? Co jsem se naučil? Co se mi podařilo? Vjaké situaci jsem nejistý? Jak reaguji, když něco nevím? Na co bych se měl více soustředit? Proč jsem se zlepšil/zhoršil (upraveno dle Kolář, Šikulová, 2009) Takto formulované otázky mohou mít regulativní, motivační i poznávací funkci, a to jak v průběhu procesu učení, tak $\mathrm{v}$ jeho závěru.

\section{Výzkumná sonda}

Cílem sondy bylo reflektovat hlavní témata týkající se rozvoje a formování sebepojetí žáků a osobní pohled učitelů primárních škol na jejich strukturu. Výzkumná sonda byla realizována prostřednictvím metody SEIQoL. Zkratka SEIQoL v označuje tzv. Program hodnoceni individuálni kvality života (,Schedule for the Evaluation of Individual Quality od Life"). (Křivohlavý, 2003) Jedná se o kvalitativní nástroj, převážně užívaný ke zjišt’ování kvality života $\mathrm{v}$ psychologických a lékařských oborech. $\mathrm{V}$ rámci individuální charakteristiky jedinců a jejich názorů byla metoda SEIQoL, ve výzkumné sondě, aplikována na problematiku formování sebepojetí žáka ve školních podmínkách. Tato metoda vede respondenta $\mathrm{k}$ zamyšlení nad vlastními životními zkušenostmi i profesními cíli. Ty jsou chápány jako zdroj motivace a osobního zaměření.

\section{Soubor / participanti}

Pro potřeby výzkumné sondy byl proveden anketní výběr učitelů primárních škol převážně z Olomouckého kraje. Vzorek se skládal z učitelů různých věkových skupin i délky praxe. Nejčastěji zastoupenou kategorií byly učitelky ve věku 41-50 let s pedagogickou praxí 11-20 let. Druhou nejpočetnější kategorií byly učitelky mladší než třicet let. Cílová a následně i realizovaná velikost vzorku činila 15 respondentů $\mathrm{z}$ toho dva muži a třináct žen.

\begin{tabular}{|l|l|l|l|}
\hline $\begin{array}{l}\text { Č́íslo } \\
\text { respondenta }\end{array}$ & Pohlaví & Věk & Délka praxe \\
\hline 1. & $\check{Z}$ & $<30$ & $<5$ \\
\hline 2. & $\check{Z}$ & $<30$ & $<5$ \\
\hline 3. & $\check{Z}$ & $41-50$ & $>20$ \\
\hline 4. & $\check{Z}$ & $41-50$ & $>20$ \\
\hline 5. & $\check{Z}$ & $<30$ & $<5$ \\
\hline 6. & $\check{Z}$ & $<30$ & $5-10$ \\
\hline 7. & $\check{Z}$ & $<30$ & $<5$ \\
\hline 8. & $\mathrm{M}$ & $30-40$ & $<5$ \\
\hline
\end{tabular}




\begin{tabular}{|l|l|l|l|}
\hline 9. & $\check{Z}$ & $30-40$ & $11-20$ \\
\hline 10. & $\check{Z}$ & $41-50$ & $>20$ \\
\hline 11. & $\check{Z}$ & $50<$ & $20<$ \\
\hline 12. & $\mathrm{M}$ & $41-50$ & $11-20$ \\
\hline 13. & $\check{Z}$ & $30-40$ & $11-20$ \\
\hline 14. & $\check{Z}$ & $41-50$ & $>20$ \\
\hline 15. & $\check{Z}$ & $30-40$ & $5-10$ \\
\hline
\end{tabular}

Tabulka č. 1: Sociálně-demografický profil respondentů

Ve výzkumné sondě byla aplikována zjednodušená forma šetření. Respondentům byl předložen formulář, jehož podstatou je vyjádření vlastní představy o tom, kterých pět faktorů je rozhodujících při vytváření žákova sebepojetí. (Křivohlavý, 2003) Níže uvedená tabulka prezentuje dílčí výsledky - nejčastěji uváděné faktory, které ovlivňují sebepojetí žáka.

\begin{tabular}{|l|l|l|}
\hline 1. & $10 \mathrm{x}$ & rodina \\
\hline 2. & $8 \mathrm{x}$ & kolektiv vrstevníků \\
\hline 3. & $7 \mathrm{x}$ & hodnocení \\
\hline 4. & $6 \mathrm{x}$ & škola a učitel \\
\hline 5. & $6 \mathrm{x}$ & osobní charakteristiky žáka \\
\hline
\end{tabular}

Tabulka 2: Nejčastěji uváděné faktory ovlivňujici sebepojetí žáka

Respondenti nejčastěji uváděli faktor rodiny a výchovy v rodině, následuje kolektiv vrstevníkủ a přátel, hodnocení a obecný vliv školy a učitele. Poslední nejčastěji uváděnou položkou jsou osobnostní charakteristiky žáka.

Jednotlivé položky se $\mathrm{v}$ odpovědích respondentů více či méně prolínaly. Téma hodnocení bylo $\mathrm{v}$ odpovědích uváděno jak $\mathrm{v}$ souvislosti $\mathrm{s}$ rodinou a jejími príslušníky, tak s vrstevníky dítěte, školou a učiteli. Respondenti ve svých volných odpovědích kladli velký význam na roli rodiny a svými výroky upozorňovali na potřebu podpory a posílení výchovy v rodině.

Z důvodu malého vzorku respondentů a charakteru výzkumné sondy není možné generalizovat závěry. Přesto bylo, dle předpokladů, poukázáno na fakt, že oslovení učitelé považují hodnocení žáka za klíčovou kategorii při vytváření a rozvoji jeho sebepojetí. Také proto je vhodné se uvedenému tématu podrobněji věnovat a systematicky rozvíjet sebehodnotící dovednosti žáků již od útlého věku. Pozornost učitelů by měla být zaměřena na rozvoj sebehodnocení žáků prostřednictvím hodnotících výroků ze strany učitelů $\mathrm{i}$ řízené sebereflexe. $\mathrm{S}$ tím se současně otevírají další témata vhodná ke zkoumání, a to: Liši se názory učitelů různých věkových kategorii na problematiku hodnoceni a sebehodnocení žáků? Považuji učitelé sebehodnocení zaáka za součást komplexniho hodnoceni? Liši se prístupy učitelů $k$ hodnoceni a sebehodnocení 
žáků? Liší se hodnocení a sebehodnocení žáka v rưzných vyučovacích předmětech? Je ve výuce poskytován dostatek prostoru pro rozvoj sebehodnoceni žáka? Aj.

\section{Závěr}

Článek reaguje na aktuální vzdělávací trendy v oblasti osobnostního rozvoje žáka se zaměřením na technickou výchovu. Hlavním tématem je sebepojetí žáka s ohledem na specifika technické výchovy na primární škole. Vzdělávání na prvním stupni základní školy poskytuje vzhledem $\mathrm{k}$ interdisciplinárnímu pojetí předmětů ideální prostředí pro realizaci tematicky propojených problémově i tvořivě zaměřených aktivit. Takto koncipovaná žákovská činnost umožňuje jak aplikaci dosavadních poznatků, tak rozvoj osobnostních kvalit žáka jako je např. sebepoznání, seberozvoj, sebepojetí, tvorbu žákovy hodnotové orientace aj.

Sebehodnocení žáků je prezentováno jako jedna z činností, při které formuje vlastní sebepojetí prostřednictvím konfrontace názorů na sebe sama s názory učitele i ostatních žáků.

Ve snaze konfrontovat teoretické př́stupy s edukační realitou byla realizována výzkumná sonda mapující názory učitelů na faktory ovlivňující rozvoj sebepojetí žáka, jejíž výsledky jsou v článku prezentovány. Respondenty nejčastěji uváděným faktorem byla rodina a její vliv na rozvoj sebepojetí žáka. V současné době má však rodina omezené podmínky $\mathrm{k}$ tomu, aby prováděla technickou výchovu $\mathrm{v}$ jejím plném rozsahu. Umožnuje však rozvíjet žáka $\mathrm{v}$ podobě her a různých manipulativních činností. Vzhledem k tomu nabývá na významu školní technická výchova, kde se předpokládá kooperace žáků, vzájemné srovnání i hodnocení učitelem. Př́nos technické výchovy na primární škole tedy nespočívá pouze $\mathrm{v}$ „,užitečnosti obsahu“, ale také v osobnostním rozvoji žáka.

Článek vznikl za podpory projektu Centrum teorie vzdělávání př́rodovědných oborů CZ.1.07/2.3.00/20166.

\section{Literatura}

Bajtoš, J., \& Pavelka, J. (1999). Základy didaktiky technickej výchovy. Prešov: FHPS.

Blatný, M. (2010). Psychologie osobnosti: hlavní témata, současné př́stupy. Vyd. 1. Praha: Grada.

Čábalová, D. (2006). Zkušenosti z výzkumu kooperativního vyučování na základní škole. In Současné metodologické př́stupy a strategie pedagogického výzkumu. Plzeň: Západočeská univerzita.

Čáp, J., \& Mareš, J. (2001). Psychologie pro učitele. Praha: Portál.

Ćástková, P., \& Stolinská, D. (2014). Sebereflexe žáka v technické výchově na primární škole. In. Trendy ve vzdělávání. Havelka, M., Chráska, M., Klement, M., \& Serafin, Č. roč. 2014, I, s. 31-35. ISSN 1805-8949. Dostupné z: http://www.kteiv.upol.cz/tvv_web/tvv14/tvv_2014_proceedings.pdf.

Fontana, D. (2003). Psychologie ve školní praxi. Praha: Portál, 2003.

Gracmanová, H., Urbanovská, E., \& Novotný, P. (2000). Podporujeme aktivní myšlení a samostatné učeni żákio. Olomouc: HANEX.

Jirásek, I. (2014). Fenomén putování jako symbol duchovního rozměru osobnostního rozvoje v diskursu zážitkové pedagogiky. Pedagogická orientace, roč. 24, 2014, č. 1, s. 
5-21. Dostupné na WWW:

http://www.ped.muni.cz/pedor/archiv/2014/PedOr14_1_p5_Fenomen_Jirasek.pdf Kasíková, H. (2001). Kooperativni učení a vyučování: Teoretické a praktické problémy. Praha: Univerzita Karlova, Nakladatelství Karolinum.

Kolář, Z., Šikulová, R. (2007). Vyučování jako dialog. Praha: Grada Publishing a.s. Koštálová, H., Miková, Š. \& Stang, J. (2012). Školní hodnocení žáků a studentů: se zaměrením na slovni hodnocení. Vyd. 2. Praha: Portál.

Kropáč, J. st., \& Kropáč, J. ml. (2009). Hodnocení techniky jako obsah výuky technických předmětů na ZŠ. In Trendy ve vzdělávání 2009. Informační technologie a technické vzdělávání: Díl I. Olomouc: Univerzita Palackého, Moravská vysoká škola, s. $88-91$.

Křivohlavý, J. (2003). Psychologie zdraví. 2.vyd. Praha: Portál.

Mammes, I. (2014). Zum Einfluss früher technischer Bildung auf die Identitätsentwicklung. Technik im Unterricht, Nr. 151, s. 5-11.

Pecina, P., \& Zormanová, L. (2009) Metody a formy aktivní práce žáků v teorii a praxi. 1. vyd. Brno: Masarykova univerzita.

Průcha, J., Walterová, E. \& Mareš, J. (2003). Pedagogický slovník. 4. aktualizované vydání. Praha: Portál.

Riedl, A. (2010). Didaktik I - Grundlagen [online]. München : Technische Universität, 2003 - [cit. 2004-11-15]. Dř́ve dostupné na WWW: <http://www.paed.ws.tum.de/>.

Roben, P. (2013). Allgemeine probleme - technische Kompetenz und technische Bildung. Technik im Unterricht, Nr. 149, S. 5-11.

Slavík, J. (1999). Hodnocení v současné škole: východiska a nové metody pro praxi. Vyd. 1. Praha: Portál.

Stephenson, N. (2013). Introduction to Inquiry Based Learning. [online]. [cit. 2014-0617]. Dostupné z: http://www.teachinquiry.com/index/Introduction.html

Vágnerová, M. (2010). Psychologie osobnosti. Vyd. 1. Praha: Karolinum. 